\title{
微小なる水蒸氣分壓中に於る金屬クローム の酸化還元平衡
}

(昭和光年十月一日受領昭和无年十一月甘五日印刷)

青山啋 $\rightarrow$ 神时菂藏

\section{I 緒 論}

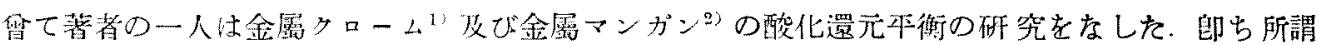

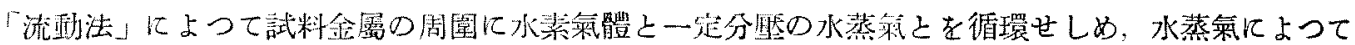

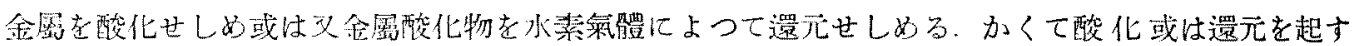

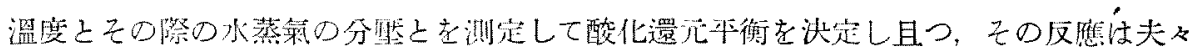

$$
\mathrm{Cr}_{2} \mathrm{O}_{3}+3 \mathrm{H}_{2} \rightleftarrows 2 \mathrm{Cr}_{\mathrm{r}}+3 \mathrm{H}_{2} \mathrm{O}
$$

或は $\quad \mathrm{HnO}+\mathrm{H}_{2} \rightleftarrows \mathrm{Mn}+\mathrm{H}_{2} \mathrm{O}$

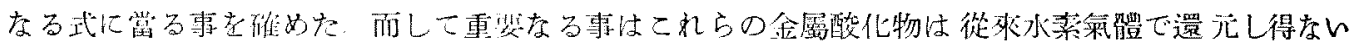

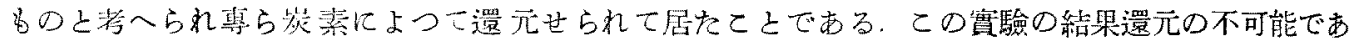

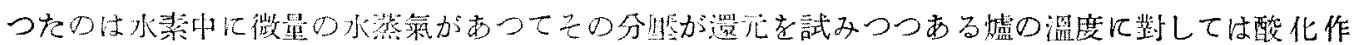

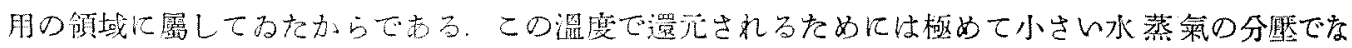

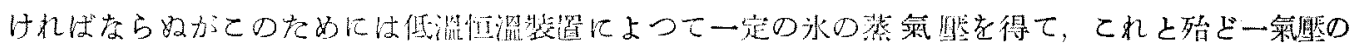

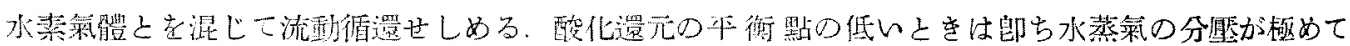

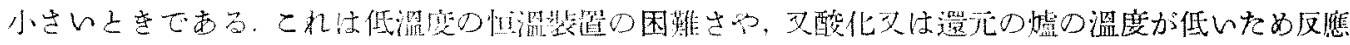

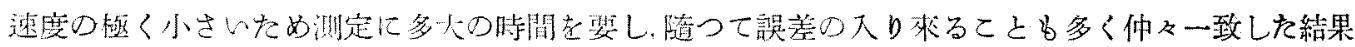

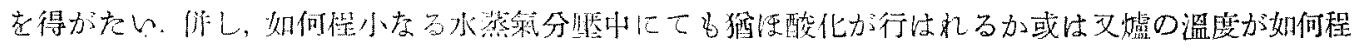

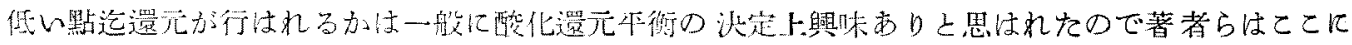

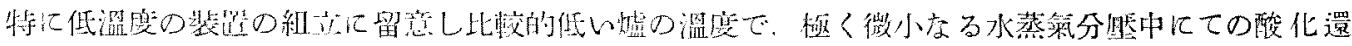

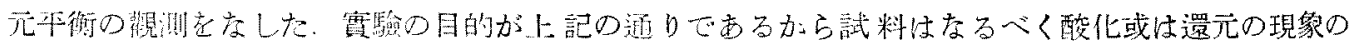

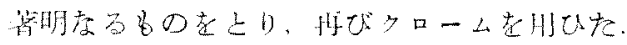

\section{II 䔈 驗 の 部}

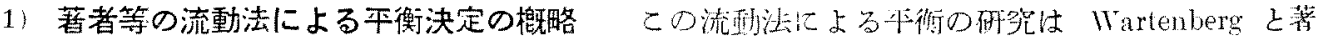

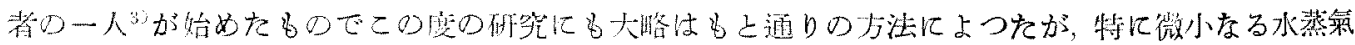

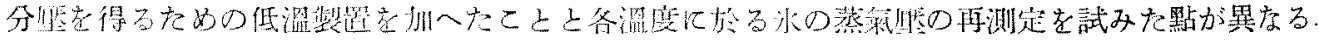

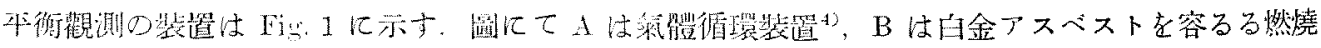

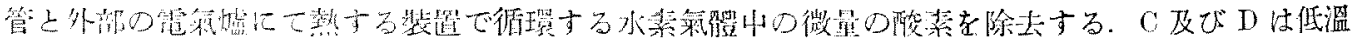

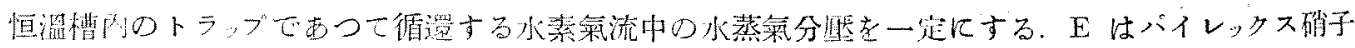

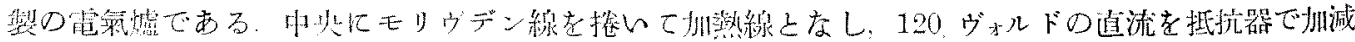

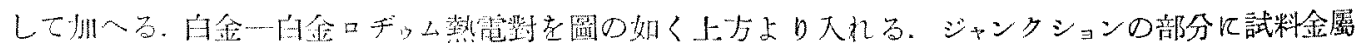

1) Wartenberg n. Aoyma: Z. Jlekchem., 33 (1927), 144.

2) 青山, 㡐：日本化學曾誌 53 (1932)， 417

3) Wartenberg \& Augana, 前出.

4) 演山，阔：前出。 


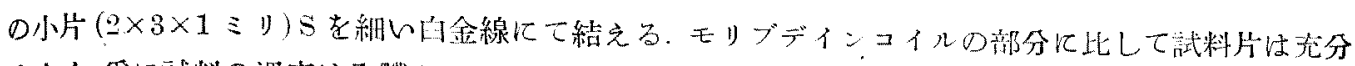

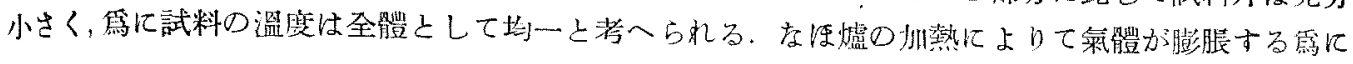

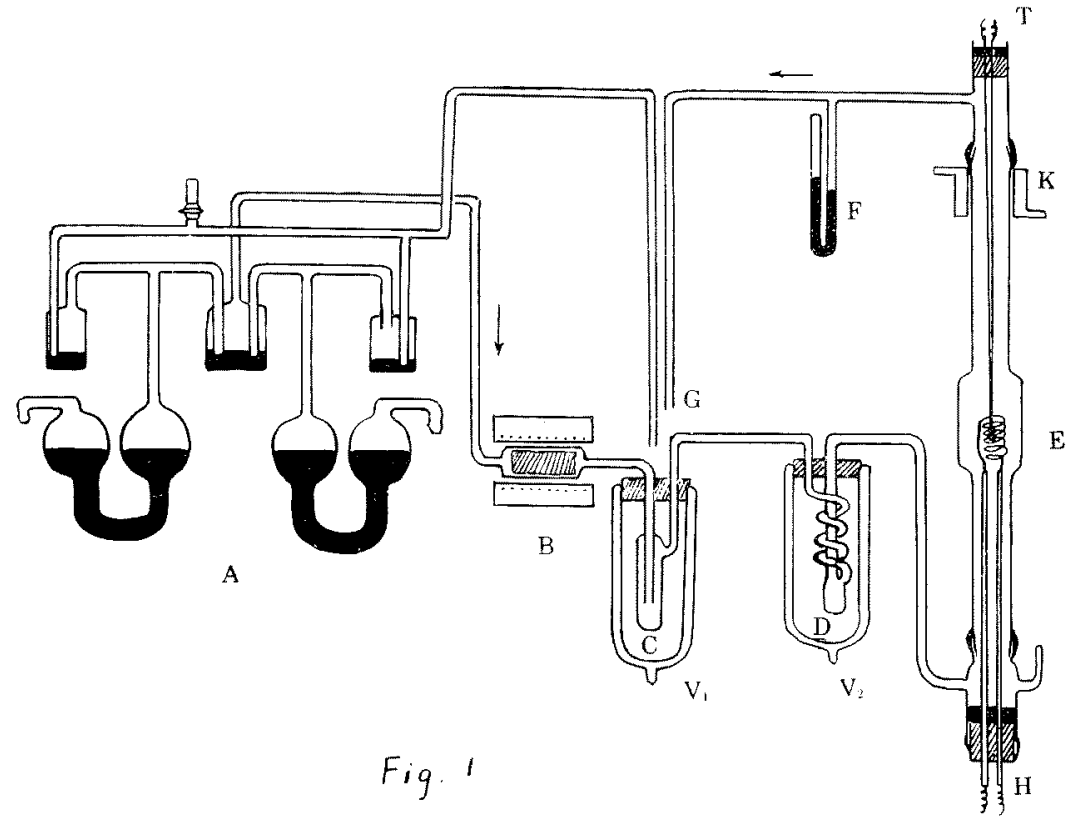

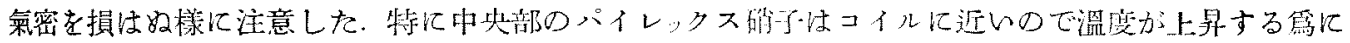

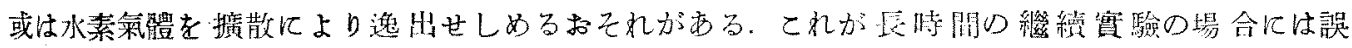

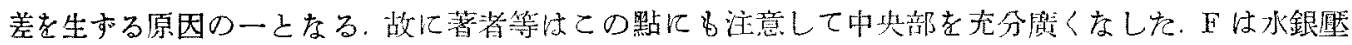

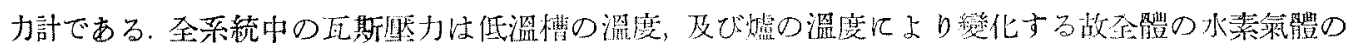

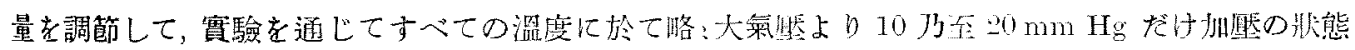

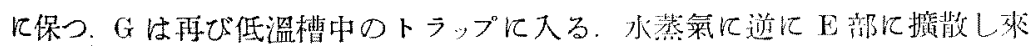

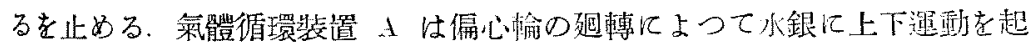

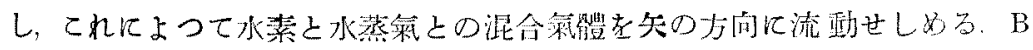

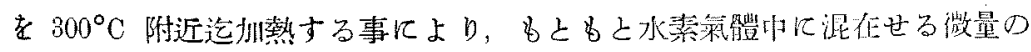

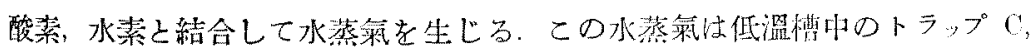

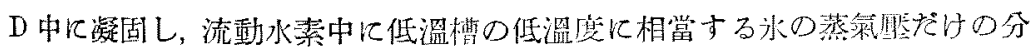
疸を興へる.

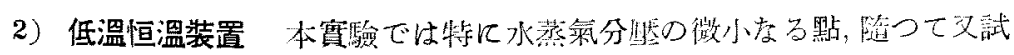
料の酸化還元平衡の溫度比较的低を點の测定に重をを执いた。故に酸化或は

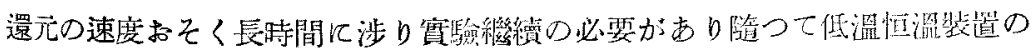

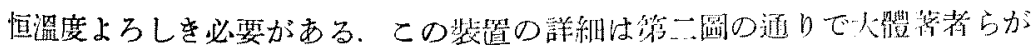
會つて水素寒暖計で熱電對の檢度をなした祭に用ひたのと同㥞である゙。

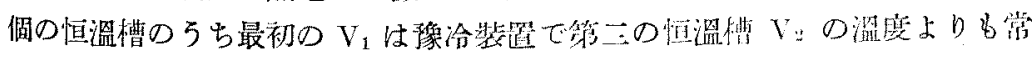

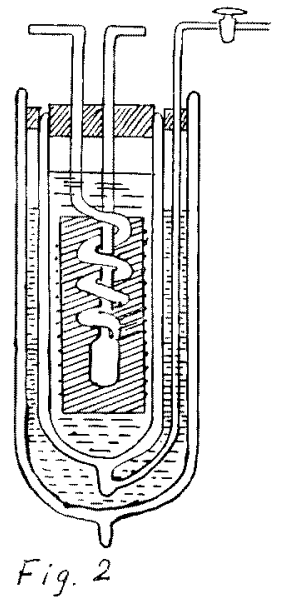

1) 葪山, 神田：日本化學會誌，55(1933), 15 . 


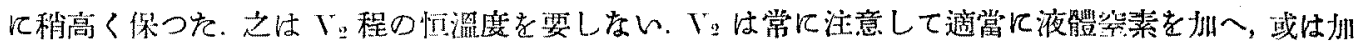

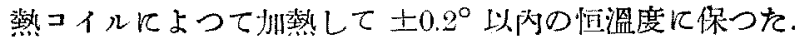

3）酸化還元平衡の觀測酸化或は還元をなすために試料を州熱するに際し，豫め白金アスベス トを䓡し，且つトラップを所定の低溫度に洽却して 5 時間餘戒體を循環せしめる. 之は微量の酸素を 除上し, 且つ完全に所定の微小なる水蒸氮分照をするためである. その後爐の溫度を一定の點迄上

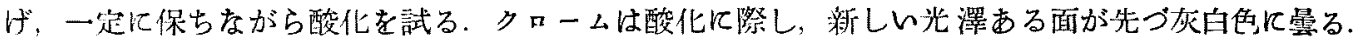

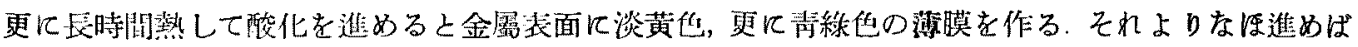

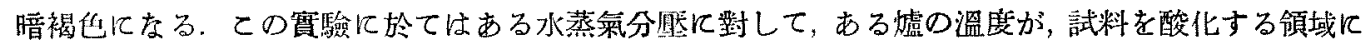
ありや, 還元する領域にありやを檢すれば巵いから，州熱コイルの㗂間より試料を觀察して，灰白色

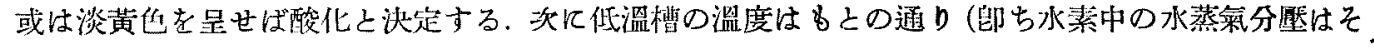

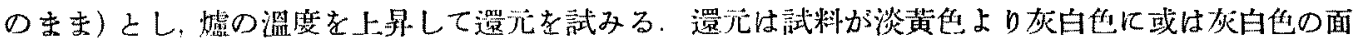
が光澤を出すに至る有樣を觀察して汽䇥する. もしての際の嘘の溫度がを酸化の領域に屬するな らば、符一包の酸化より，更に酸化が非行して, 表面の黄色が深まるのを認める.かくの如く或る一定

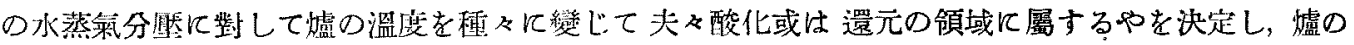

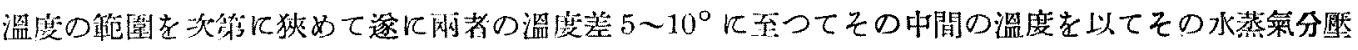

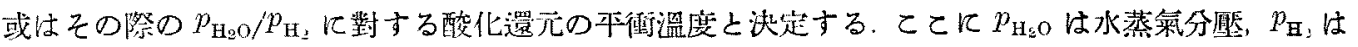

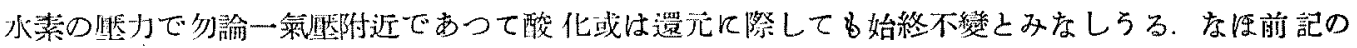

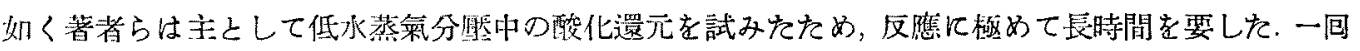
の酸化を認めるに百時問以上を費すが如を場合は可論繼續賽驗をなす必要なく，爐を常溫になして， 酸化或は還元の途中の儖となし，再開始に際しては豫め数時間の水素の精製循還を行つた。

\section{III 平衡觀測の結果}

低溫槽の䡔度 $-20^{\circ} \mathrm{C},-39^{\circ} \mathrm{C},-58^{\circ} \mathrm{C},-78.5^{\circ} \mathrm{C},-93^{\circ} \mathrm{C},-101^{\circ} \mathrm{C},-130^{\circ} \mathrm{C}$ 等にて試みた結果 は次のやちである。

1) 低溫榑の溫度 $-20.0^{\circ} \mathrm{C}$

\begin{tabular}{|c|c|c|c|c|}
\hline 燃の溜落 & 晨初の武料 & 反應洔間 & \multicolumn{2}{|c|}{ 試料の整化 } \\
\hline $\begin{array}{l}1100^{\circ} \\
1200^{\circ} \\
1145^{\circ} \\
1110^{\circ} \\
1145^{\circ} \\
1131^{\circ}\end{array}$ & 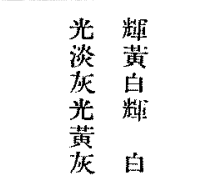 & $\begin{array}{l}6 \\
4 \\
6 \\
6 \\
5 \\
5 \\
4\end{array}$ & 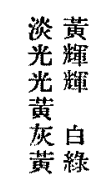 & 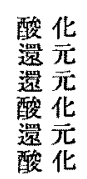 \\
\hline
\end{tabular}

平衡點 $1131^{\circ} \sim 1145^{\circ}$ 即方 $1136^{\circ} \mathrm{C}$ とす

2) 低渭槽の溫度 $-39^{\circ} \mathrm{C}$

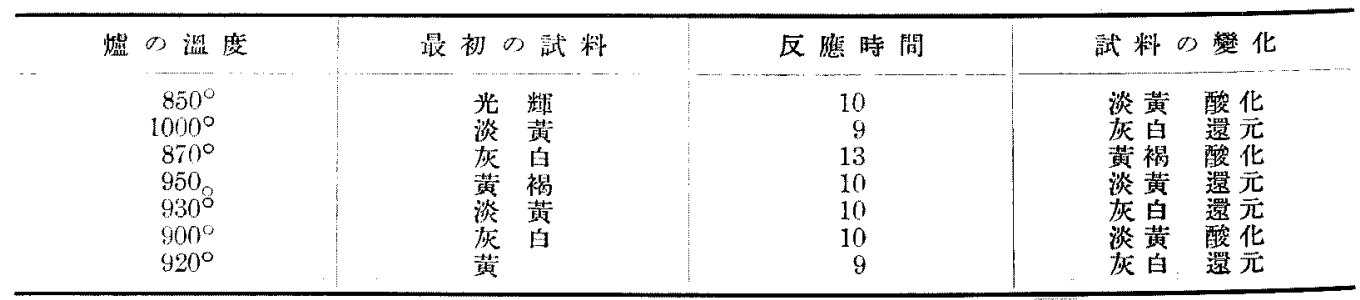

区微默 $990^{\circ} \mathrm{C} \sim 930^{\circ} 925^{\circ} \mathrm{C}$ 
3）低溫槽の溫度 $-58^{\circ} \mathrm{C}$

\begin{tabular}{|c|c|c|c|c|}
\hline 譃の偲度 & 最初の試料 & 反悲時闊 & \multicolumn{2}{|c|}{ 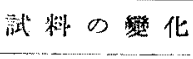 } \\
\hline $700^{\circ}$ & 光 知 & 15 & 黃褐 & 酸 化 \\
\hline 800 & 琵 衸 & 14 & 灰白 & 還 元 \\
\hline 725 & 炏 白 & 15 & 褐 & 酸 化 \\
\hline 780 & 䶂 & 10 & 淡谓 & 遙 \\
\hline 755 & 淡 黄 & j & 灰白 & 遝元 \\
\hline 740 & 灰 白 & 10 & 黃 & 酸 化 \\
\hline 755 & 黄 & 8 & 淡黃 & 管元 \\
\hline
\end{tabular}

平衡溫度 $755^{\circ} \sim 740^{\circ} \quad 747.5^{\circ} \mathrm{C}$

4) 低溫槽の溫度 $-78.5^{\circ} \mathrm{C}$

\begin{tabular}{|c|c|c|c|c|}
\hline 䲣の毗度 & 最初の訴料 & 反热時闗 & 試料。 & 楚 化 \\
\hline $510^{\circ}$ & 光 埰 & 30 & 黄 褐 & 化 \\
\hline 700 & 装 裼 & 20 & 作白 & 邆 䒕 \\
\hline 550 & 灰 白 & 28 & 黄䶂 & 陵化 \\
\hline 650 & 笛: 褐 & 30 & 灰白 & 邀元 \\
\hline 595 & 施 白 & 20 & 黄 & 酸化 \\
\hline 611 & 策 & 20 & 淡葨 & 遏 元 \\
\hline
\end{tabular}

平淮溫度 $595^{\circ} \sim 611^{\circ} 603^{\circ} \mathrm{C}$

5) 低温槽の湿度 $-93^{\circ} \mathrm{C}$

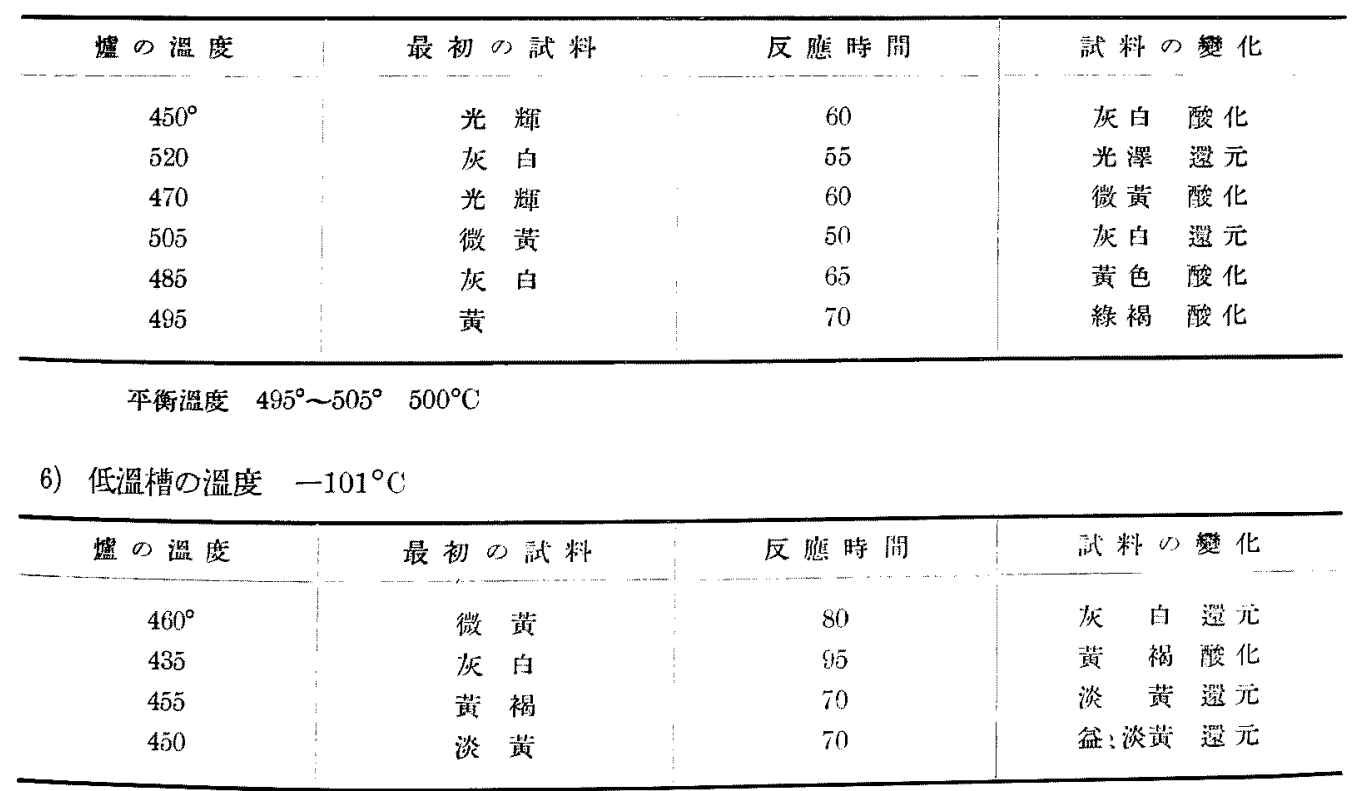


な泜溫槽の温度 $-130^{\circ} \mathrm{C}$ 爐の溫度 $350^{\circ} \sim 420^{\circ} \mathrm{C}$ にて試みねが酸化が起らなかつた. 斯く高溫 の酸化還元暃衝より exterpolateして酸化飞屬する溫度䡉園にて長時間 (120 時間餘)の實驗の結果, な酸化をみないのは，堵の溫度低いため酸化の反應速度甚だ小さきにると考える。

上記の諸點に於る測定の結果よりの平衡恒數＼cjkstart觀测を試みた場 合の低溫恒溫槽の溫度に於る氷 の蒸篓埾をDoudt の式より算出して $p_{\mathrm{H}_{2} \mathrm{O}} / p_{\mathrm{H}_{2}}=\mathrm{K}$ なる平衡恒數を各平衡點につを決定する. 流動法

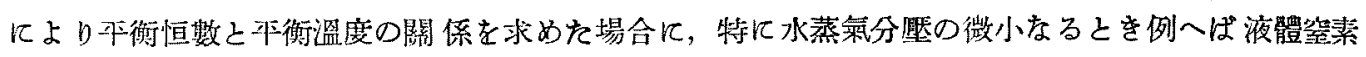

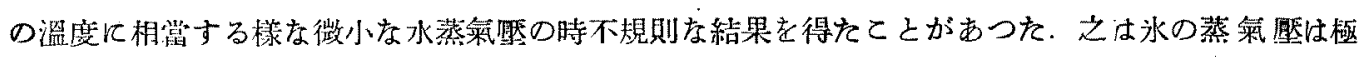
く低溫度にては Doudt の式と一致しないためかと考へて念のため低溫度に於る水の蒸氣厴の再测定

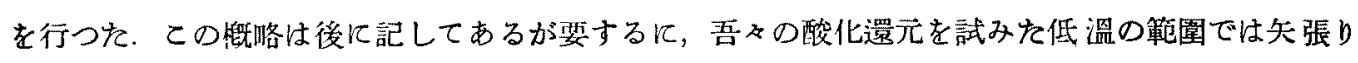
Dondt の理論式と一致する結果を得た.

Doudt $の$ 式

$$
\log p=-\frac{2611.7}{T}+1.75 \log T-0.00210 T+6.5343 \text { よ }
$$

$$
\begin{array}{ccccccc}
t & -20^{\circ} \mathrm{C} & \multicolumn{1}{c}{-39^{\circ}} & -58^{\circ} & -78.5^{\circ} & \multicolumn{1}{c}{-93^{\circ}} & \multicolumn{1}{c}{-101^{\circ}} \\
\log p_{\text {atm }} & -2.9869 & -3.8682 & -4.9520 & -6.1060 & -7.2458 & -7.9524 \\
p_{\text {mm B }} & 0.7833 & 0.1038 & 0.0_{2} 8488 & 0.0_{3} 5954 & 0.0_{4} 4315 & 0.0_{5} 8480
\end{array}
$$

而して $2 \mathrm{Cr}+3 \mathrm{H}_{2} \mathrm{O} \rightleftarrows \mathrm{Cr}_{2} \mathrm{O}_{3}+3 \mathrm{H}_{2}$ なる平衡にて平衡恒數は $K=\frac{p_{\mathrm{H}_{2}}^{3}}{p_{\mathrm{H}_{2} \mathrm{O}^{3}}}$ であり.この $p_{\mathrm{H}_{2} \mathrm{O}}$ は上 記の理論式よりの值を用ひた，簢單のため $K^{\prime}=3 \sqrt{\frac{1}{K}}$ となけば $K^{\prime} \fallingdotseq p \mathrm{H}_{2} \mathrm{O}$ となる.かくて夫ネの平 衡點に於る $\mathrm{K}$ を表記しておけば

\begin{tabular}{c:c|c}
\hline 低溫槽の溫度 & 平衡點 & $\log K^{\prime}$ \\
\hline$-20^{\circ}$ & $1136^{\circ} \mathrm{C}$ & -2.9869 \\
$-39^{\circ}$ & $925^{\circ}$ & -3.8682 \\
$-58^{\circ}$ & $747^{\circ}$ & -4.9520 \\
$-78.5^{\circ}$ & $602^{\circ}$ & -6.1060 \\
$-93^{\circ}$ & $500^{\circ}$ & -7.2458 \\
$-101^{\circ}$ & $445^{\circ}$ & -7.9524 \\
\hline
\end{tabular}

平衡點の紹對溫度と $K$ の間には $\mathrm{F}$ の實 驗式が成り立つ.

$$
\log K^{\prime}=-\frac{7341}{T}+2.250
$$

Fig. 3 に示す.

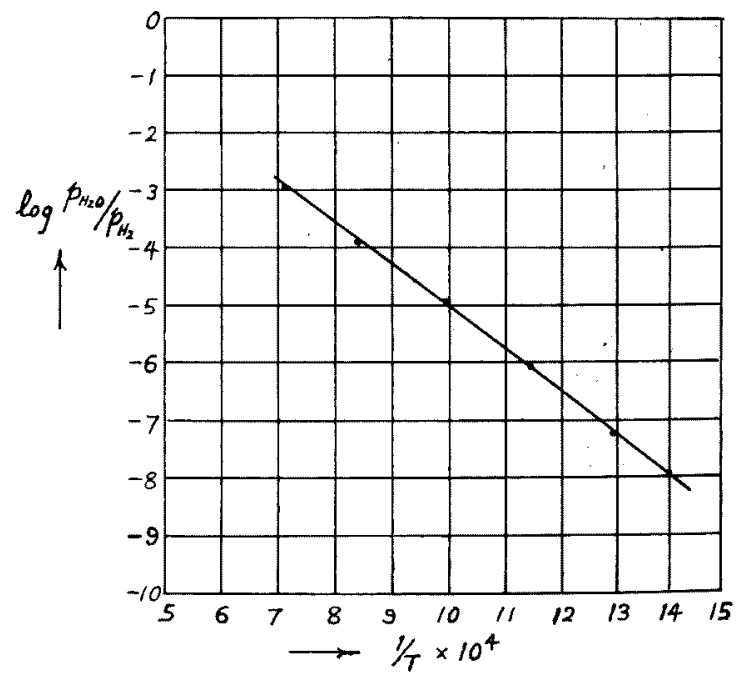

Fig. 3

この貫驗式は Nernst の平衡つ近似式の意義より考へて $7341 \times 4.571 \times 3=100667 \mathrm{cal}$ は上記平衡に 於る反應熱の近似佔几相當する。 


\section{IV 反應熱, 遊離エネルギー等の算出}

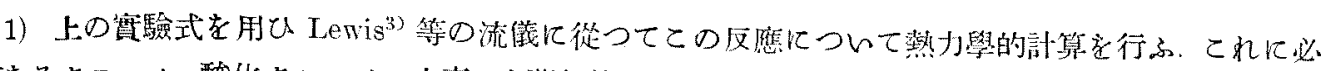

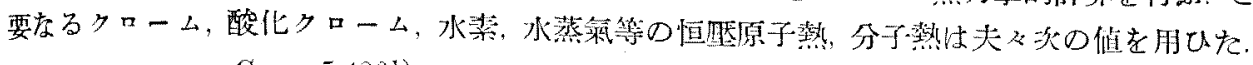

$$
\begin{aligned}
& C_{\mathrm{Cr}}=5.406^{12} \\
& C_{\mathrm{Cr}_{2} \mathrm{O}_{3}}=27.4^{2)} \\
& C_{\mathrm{H}_{2}}=6.50+0.0009 T^{3)} \\
& \left.C_{\mathrm{H}_{2} \mathrm{O}}=8.81-0.0019 T+0.0_{5} 222^{23}\right)
\end{aligned}
$$

之よりこの反應の反應熱, 自由エネルギーは夫ぬ

$$
\begin{aligned}
& \lrcorner H=J H_{0}+9.66 T+0.0 .42 T^{2}-0.05222 T^{3} \\
& \lrcorner F=\lrcorner H_{0}-9.66 T \ln T-0.0_{2} 42 T^{2}+0.0_{5} 111 T^{3}+I T
\end{aligned}
$$

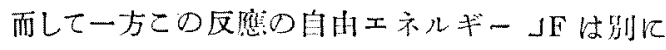

$$
\Delta F=-R T \ln K=-R T \ln \frac{p_{\mathrm{II}_{2}}^{\mathrm{z}}}{p_{\mathrm{n}, \mathrm{O}}^{\mathrm{z}}}
$$

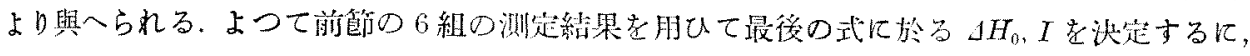

$$
\begin{aligned}
\Delta H_{0} & =-111173 \mathrm{cal} \\
I & =111.43
\end{aligned}
$$

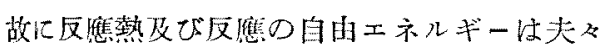

$$
\begin{aligned}
& J H=-111178+9.66 T+0.0_{2} 42 T^{2}-0.0_{5} 222 T^{3} \\
& \Delta F=-111173-22.24 T \log T-0.0_{2}+2 T^{2}+0.0_{5} 111 T^{3}+111.43 T
\end{aligned}
$$

により與一られ $25^{\circ} \mathrm{C}$ に於る夫は

$$
\begin{aligned}
& \Delta H_{: 9 s}=-107980 \mathrm{cal} \\
& \Delta F_{999}=-112502 \mathrm{cal}
\end{aligned}
$$

となる。

2）酸化タロームの生成熱及び分解㫜

$$
\begin{aligned}
& 2 \mathrm{Cr}+3 \mathrm{H}_{2} \mathrm{O} \rightleftarrows \mathrm{Cr}_{2} \mathrm{O}_{3}+3 \mathrm{H}_{2} \text { につをては } \\
& \Delta F_{298}=-112502 \mathrm{cal} \quad \Delta H_{295}=-107980 \mathrm{cal}
\end{aligned}
$$

又水蒸策の生成につをては4

$$
\begin{aligned}
3 \mathrm{H}_{2}+3 \mathrm{O}_{2} & \gtrless 3 \mathrm{H}_{2} \mathrm{O} \mathrm{K} \tau \\
\Delta F_{298} & =-163521 \mathrm{cal} \quad \Delta H_{998}=-173460 \mathrm{cal}
\end{aligned}
$$

そらより $2 \mathrm{Cr}+3 \mathrm{O}_{2} \rightarrow \mathrm{Cr}_{2} \mathrm{O}_{3}$ Kては

$$
\Delta F_{999}=-276023 \mathrm{cal} \quad \Delta H_{999}=-281440 \mathrm{cal}
$$

酸化クロームの生成熱につんて Mixter ${ }^{b /}$ は $\Delta H=276.8 \mathrm{Kal}$ を其へてるる.

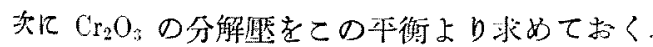

$2 \mathrm{Cr}+3 \mathrm{H}_{2} \mathrm{O} \gtrless \mathrm{Cr}_{2} \mathrm{O}_{3}+3 \mathrm{H}_{2} \quad \kappa$ 於子 $J F=-R T \ln K=-R T \ln \frac{p_{\mathrm{H} 2}^{3}}{p_{\mathrm{H} ; 0}^{3}}$

を $3 \mathrm{H}_{2}+\frac{3}{2} \mathrm{O}_{2} \gtrless 3 \mathrm{H}_{2} \mathrm{O}$ に於る $\Delta F^{\prime}=-R T \ln \frac{p_{\mathrm{H}_{2} \mathrm{O}}^{3}}{p_{\mathrm{H}_{2}}^{3} p_{\mathrm{O}_{2}}^{3 / 2}}$

1) Lämmel: Ann. Physs., 16 (1905), 551.

2) Russel: $L 7 y / s . Z ., 13$ (1912), 59.

3) LewisRandall: 'Thermodynamik.' 4) Derby: J. Am. Chem. Sor, 36 (1914). 709. 5) Mixter: Z. anory. Chem., 92 (1915), 366., Sill. J., 126 (1908), 125 


$$
\begin{aligned}
& \Delta F+\Delta F^{\prime}=-R T \ln \frac{1}{p_{\mathrm{O} 2}^{3 / 2}} \\
& \therefore \quad \ln p_{\mathrm{O} 2}=\frac{2}{3} \frac{\Delta F+\Delta F^{\prime}}{R T} \quad \text { or } \quad \log p_{\mathrm{O} 3}=\frac{2}{3} \frac{\Delta F+\Delta F^{\prime}}{4.571 T}
\end{aligned}
$$

而して水蒸氣につレては

$$
J F^{y}=-172230+2.82 \times 2.303 T \log T+4.95 \times 10^{-3} T^{2}-11.1 \times 10^{-7} T^{3}+10.98 T
$$

之と前記の $\Delta F$ の式とより，

$$
\log p_{O_{2}}=\frac{1}{3 \times 4.571}\left\{-\frac{283403}{T}-15.75 \log T+0.00075 T+122.4\right\}
$$

之上り各溫度に於る $\mathrm{Cr}_{2} \mathrm{O}_{3}$ の解離酿を算出するに次の如くなる。

\begin{tabular}{c|c|c|c|c|cc}
\hline$T$ & 1409 & 1198 & 1020 & 875 & 774 & 715 \\
\hline$p_{O 3}$ & $2.02 \times 10^{-19}$ & $2.57 \times 10^{-24}$ & $1.37 \times 10^{-30}$ & $9.17 \times 10^{-37}$ & $5.83 \times 10^{-43}$ & $3.97 \times 10^{-47}$ \\
\hline
\end{tabular}

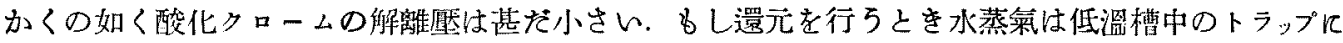

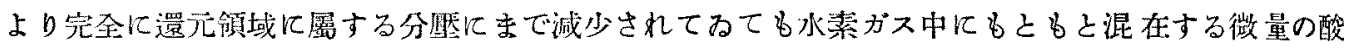

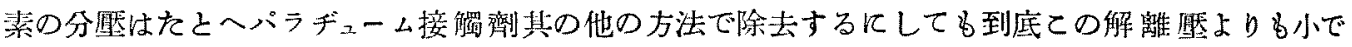

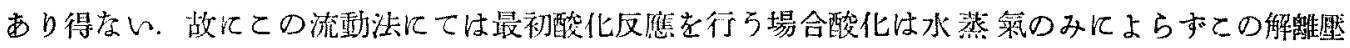

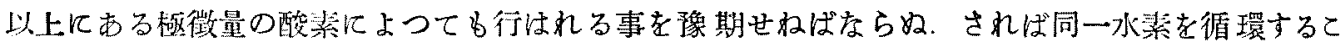
とにより，ての微量の酸絜を除いて實驗せね壮ならぬ. 作單に酸化クロームを水素により還元せんと

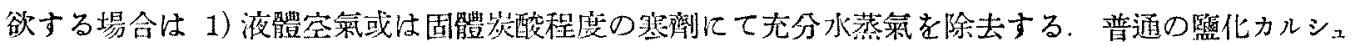
一ム等の乾燥劑では $1000^{\circ} \mathrm{C}$ 的外の溫度で還元し5る程度にしか水蒸氣を除をえない，2）解離是の

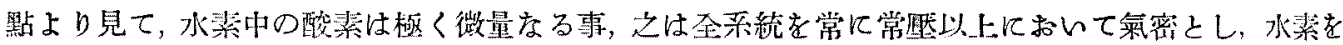
循環せしめる必要があると思注れる，而して微量の酸装を除去する装置を必姴とする。

\section{$\mathrm{V}$ 低温度に於る水の蒸氣壓}

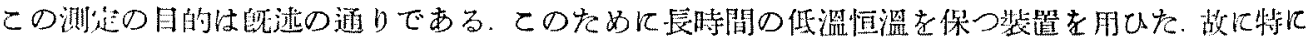
この點秒: 詳紨に記す。

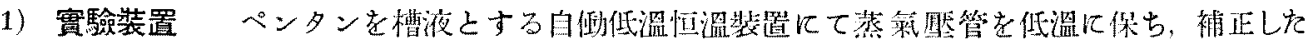

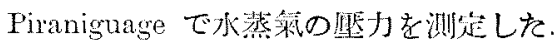

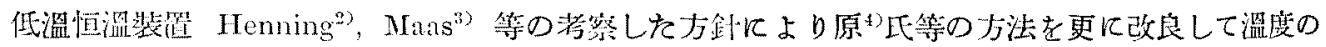

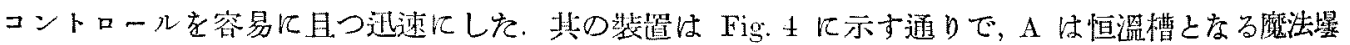

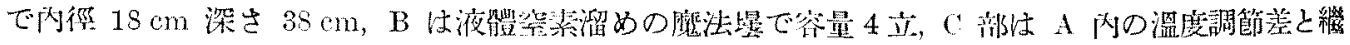

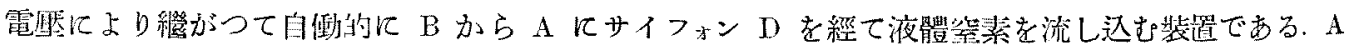

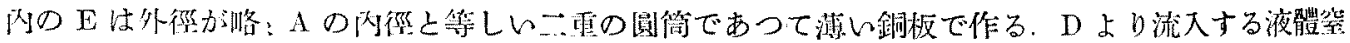
素は先づ $\mathrm{E} の$ 冈外壁間の底部に迕し，蒸發して，闪外壁間にある隔壁に從つて $\mathrm{E}$ 冈を旋回して槽液

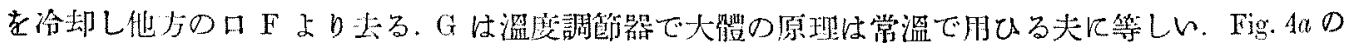

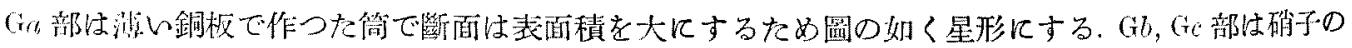

1) Lewis-Randall; 'Thermodynamik'. 2) Henning: Z. Instrklde, 33 (1913), 23. 3) Maas: J. Am. Chem. Soc., 45 (1927), 360. 4) 原, 策㗪：日本工業化學會誌, 29 (1926), 262. 


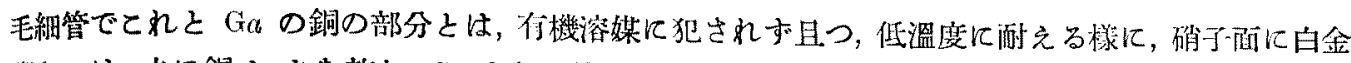

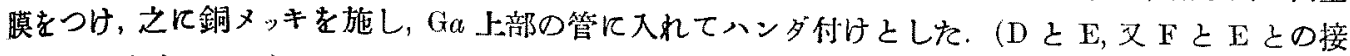

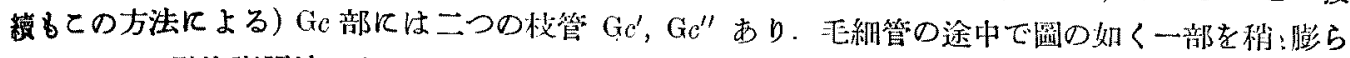
ませる.との點过膨脹液としてペンタンを入れ，てれょり先端部の二つの枝管には水銀を入れる。水 銀恃上部加らの白金線の先端と接し或は離れて溫度調節の作用をなす事は普通の調節器之全く同梯 である.而して二つの手金線と水銀線との接触は稍:そのレベルを異にする．ての部分は溫度の變化

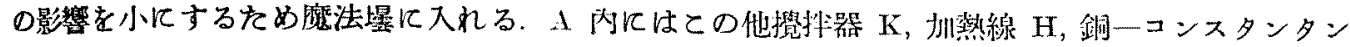

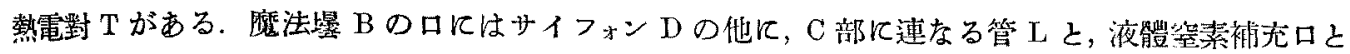
がある。

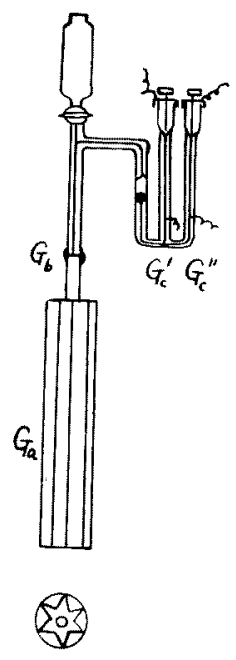

Fig. $4 a$

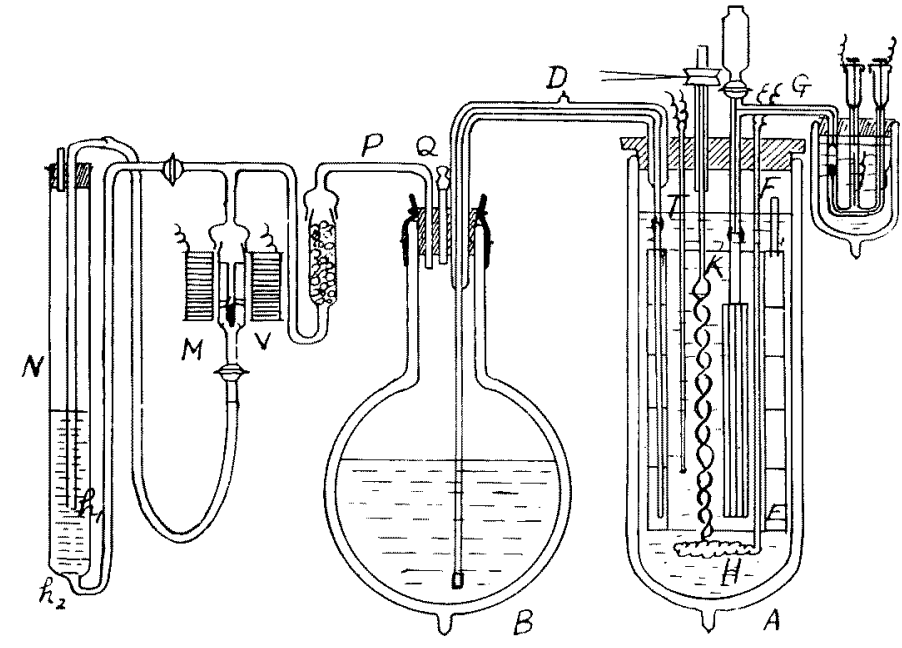

Fig. 4

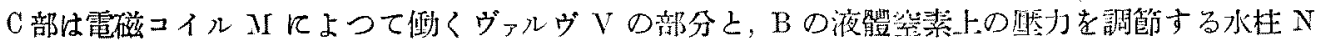

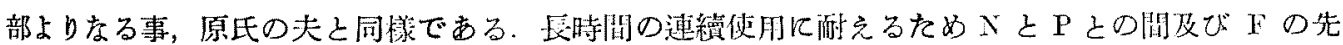

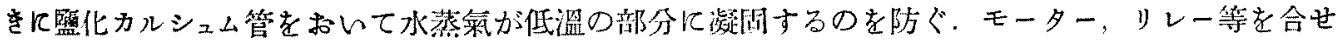

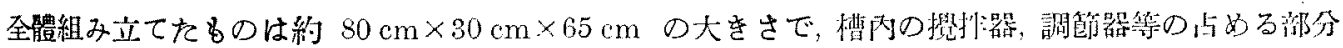
以外で利用しろる空き間は直鲉約 $10 \mathrm{~cm}$ の成筒となり，憎液として石湖エーテル或はペンタン約 4 立を容れる。

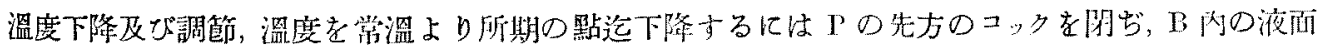

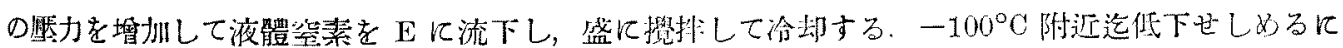
は約 2 時間斗を要する。所期の溫度附近迄下降すれぱ P の先のコックを開を

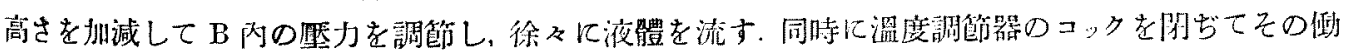

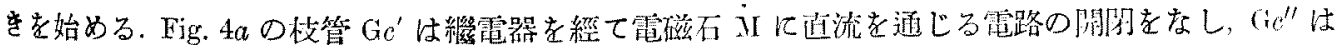

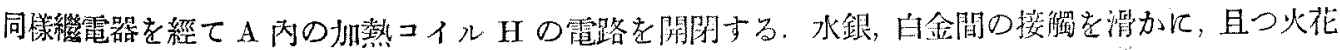

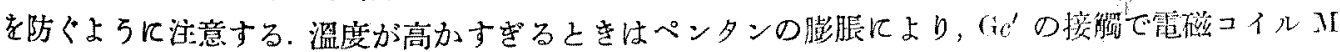

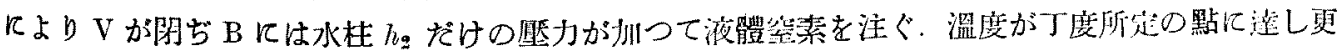

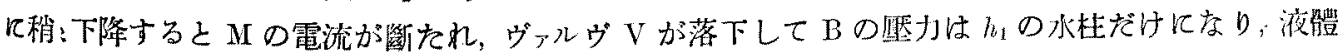




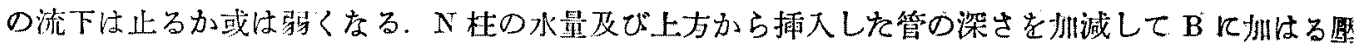
力を避當にする事は從來の夫と同核である. 但し，Bの容量大きいから，液體の減少に應してれを戀

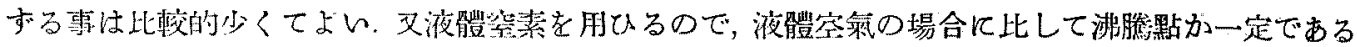
からルの高をの調節に苦心する事が非常に少くてすむ. 又始如は溫度調節器の水銀，白金接触は一 忮のみで行つたがこの埸合は，溫度下降して白金と水銀の接触が断たれ，ヴァルヴVが開らても暫時

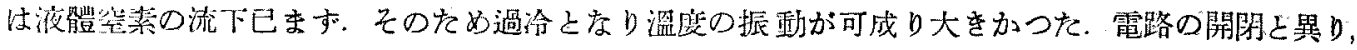

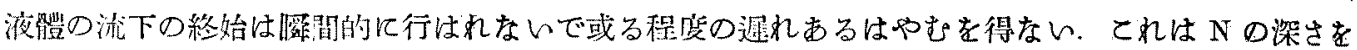
加堿する事により窒素の流下量を調節して或る程度迄は防けるが，てれがためにはN部の調節甚だ

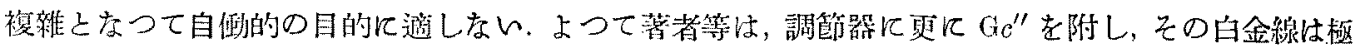

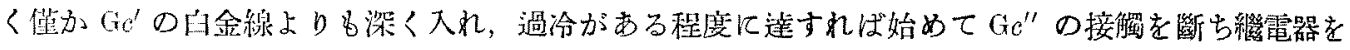

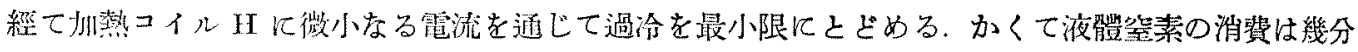

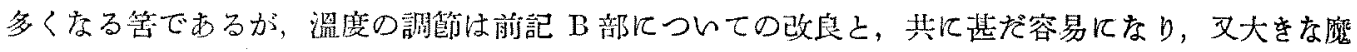
法垭は老用ひた事とも相待つて溫度の恒定度も良くなつた。冷却部に銅の二重筒を朋ひをため最初

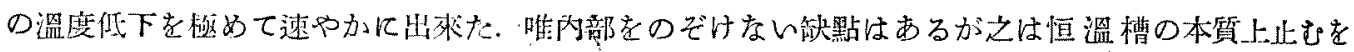
得ない. $-100^{\circ} \mathrm{C}$ 附近几調矩した際の溫度の變化の一例を Fig. 5 に示す 任意の溫度で大體 $\pm 0.02^{\circ}$ 以內の曫化である。

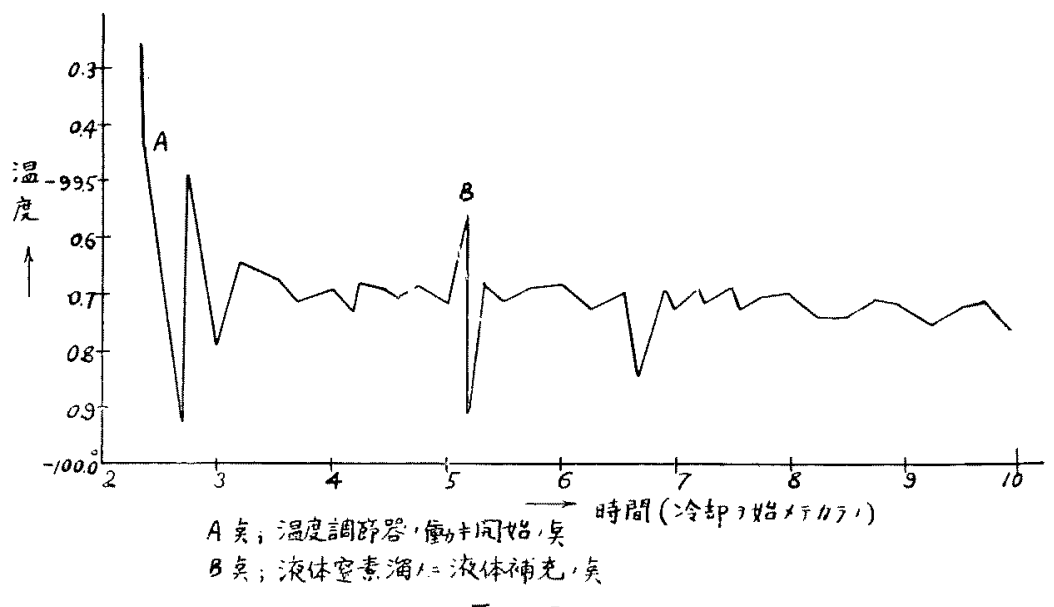

$$
\text { Fig } 5
$$

$-130^{\circ} \mathrm{C}$ 附近になるとペンタンや石油エーテル等の槽液が粘性を增し，溫度の均一を恒定がよく

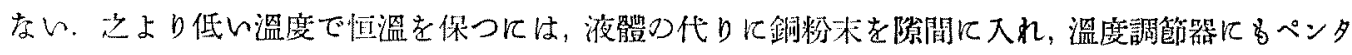
ンの代りに水装ガスを入れる。

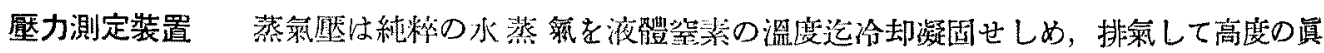

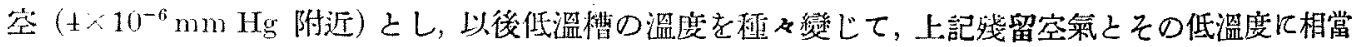

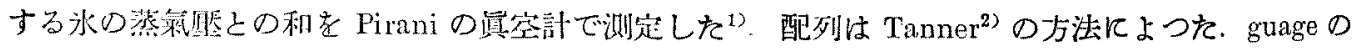

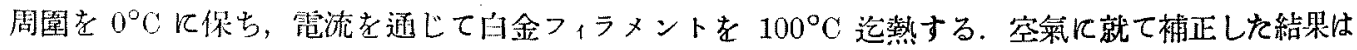

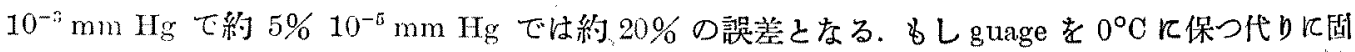

1) 教山, 种田: 日本化學會誌, 55 (1033), 23

2) Tanner: J. Phys. Chem., 34 (1930), 1113 


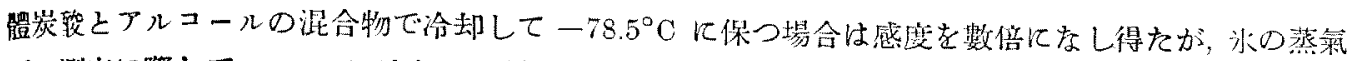

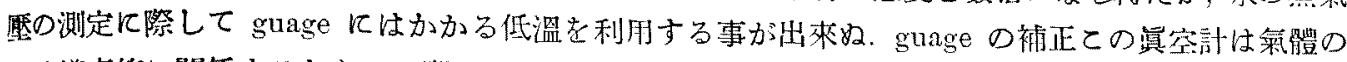

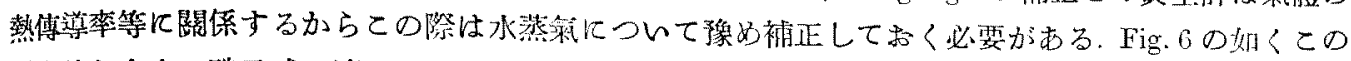

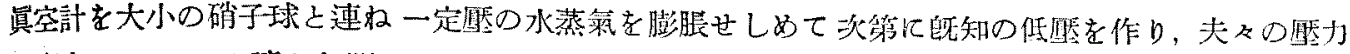

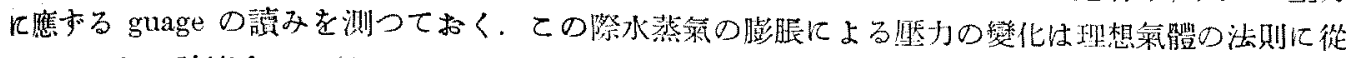

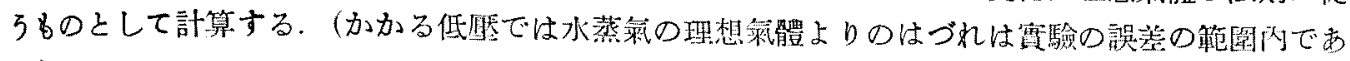
3.)

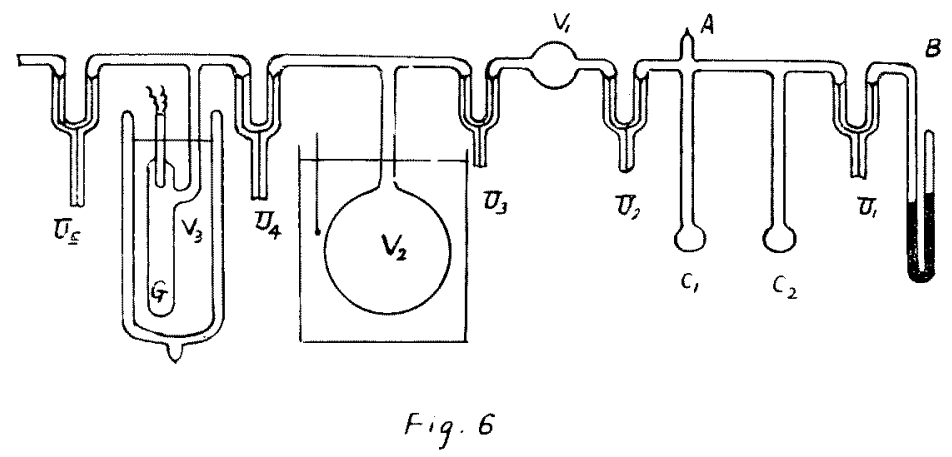

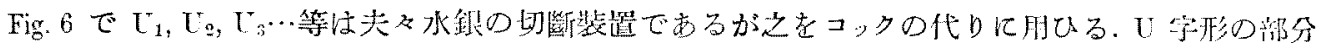

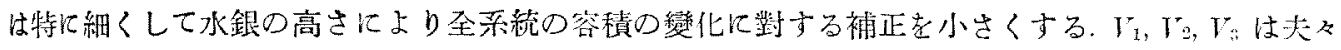

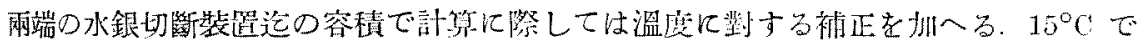

$\Gamma_{\mathrm{i}}=17.413 \mathrm{cc} \quad \mathrm{r}_{2}=1141.72 \mathrm{co} \quad \mathrm{r}_{\mathrm{s}}=40.351 \mathrm{cc}$ である

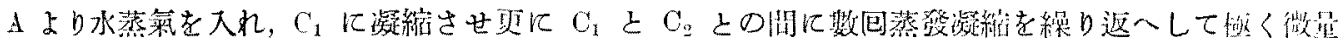

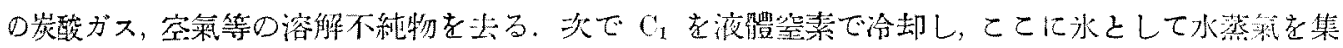

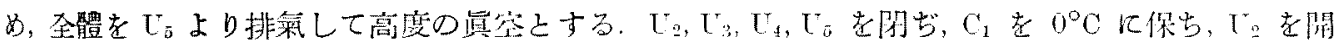

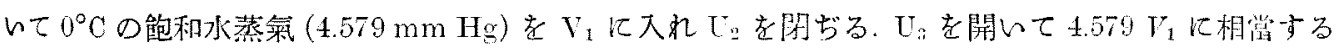

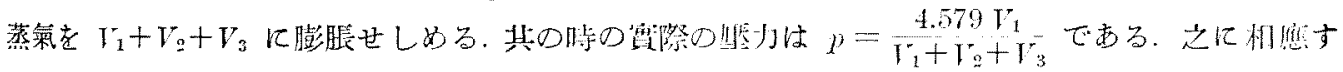

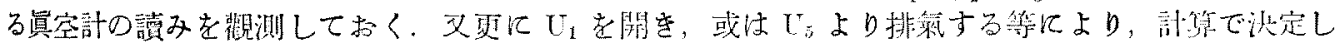

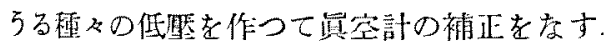

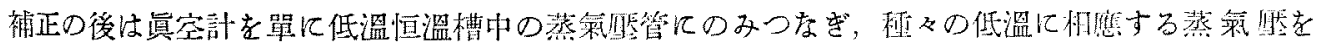

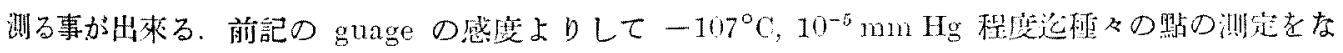
L衣.

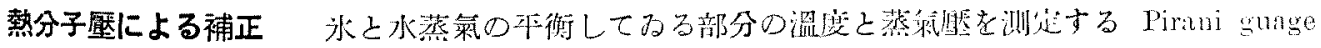

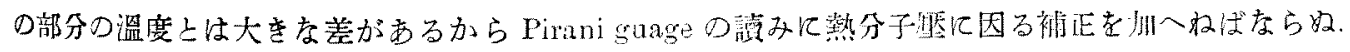

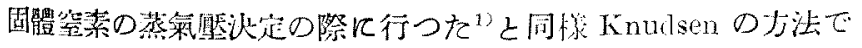

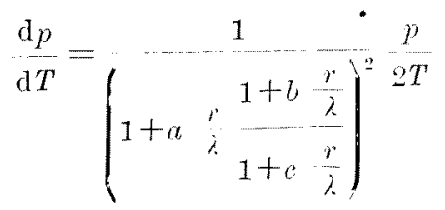

1) 静山, 种田: 日本化學合声, 55 (1933), 23 


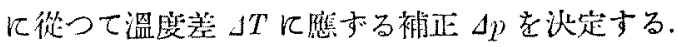

この際水蒸氣の平睹自目徑路 $\lambda$ は

$$
\lambda=\frac{1}{0.499} \sqrt{\frac{\pi}{8}} \frac{\eta_{0}}{\sqrt{\rho_{0}}} \frac{1}{p}\left(\frac{T}{273}\right)^{0.5+n}
$$

であらはす $0^{\circ} \mathrm{C}$ て於る粘性係數は $\eta_{0}=904 \times 10^{-7}$ 而して粘性係數は絕對溫度の $n=1.088$ 乘に比 例するとした。

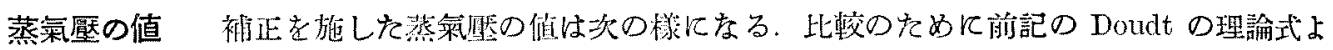

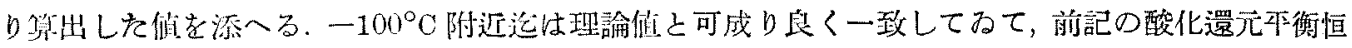

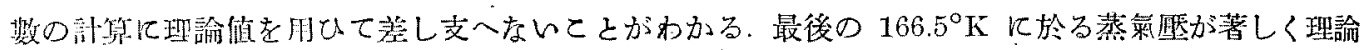

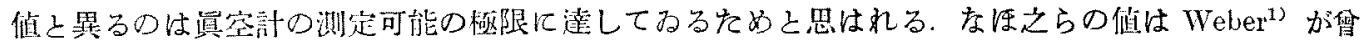
つて测起した们とる $185^{\circ} \mathrm{K}$ 迄は大體一致してるる。

\section{水 蒸 氮 盃}

\begin{tabular}{|c|c|c|}
\hline 絕 對 㴓庭” & 测定值 $(\mathrm{mm} \mathrm{Hg})$ & 理 諭 值 \\
\hline 273.2 & & 4.579 \\
\hline 264.5 & 2.15 & 2.10 \\
\hline 200.2 & 0.571 & 0.574 \\
\hline 242.9 & 0.279 & 0.283 \\
\hline 288.1 & 0.160 & 0.166 \\
\hline 223.0 & $2.90 \times 10^{-2}$ & $2.91 \times 10^{-2}$ \\
\hline 2040 & $2.40 \times 10^{-5}$ & $220 \times 10^{-3}$ \\
\hline 200.1 & $1.11 \times 10^{-3}$ & $1.18 \times 10^{-3}$ \\
\hline 192.5 & $2.90 \times 10^{-1}$ & $2.32 \times 10^{-4}$ \\
\hline 185.1 & $0.91 \times 10^{-4}$ & $1.00 \times 10^{-4}$ \\
\hline 175.2 & $2.7 \times 10^{-5}$ & $2.30 \times 10^{-3}$ \\
\hline 166.5 & $2.3 \times 10^{-5}$ & $1.60 \times 10^{-0}$ \\
\hline
\end{tabular}

\section{總括}

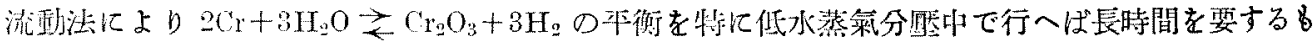

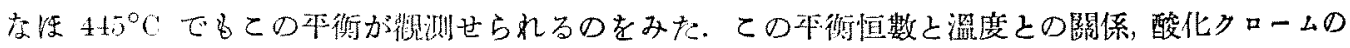

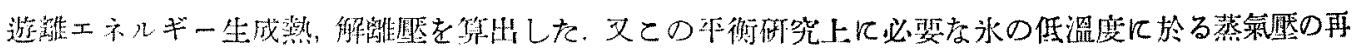

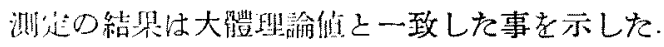

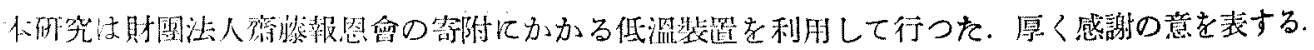

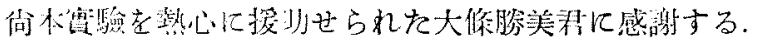

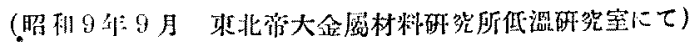

1) Webor: Cumm. Leiden, $150 a$.

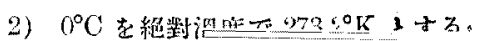

